\title{
Dynamic Relation Between Economic Growth, Stock Market Depth and Macroeconomic Variables of Bangladesh
}

\author{
Mostafa ALI*
}

Received: July 10, 2020. Revised: October 11, 2020. Accepted: October 15, 2020.

\begin{abstract}
This study explores the dynamic relation between economic growth and stock market depth in the presence of three more macroeconomic indicators such as exchange rate, inflation and interest rate of Bangladesh. We use Johansen and Juselius (1990) test of co-integration and Vector Error Correction Model (VECM) to detect the possible short-run and long-run causal relation among the selected economic forces. The results of the study evidence that the lagged error-correct term of GDP (i.e., the proxy of economic growth) is found statistically significant in all three models. This manifest that GDP tends to converge to its long-run equilibrium path in response to changes in its regressors. But we find a complex network of causal linkage between the variables in the short-run. The findings of this study are of particular interest and importance to policymakers, financial managers, financial analysts and investors dealing with the Bangladesh economy and the Bangladesh stock market.
\end{abstract}

Keywords: Economic Growth, Stock Market Depth, Macroeconomic Variables, Vector Error Correction Model (VECM), Bangladesh.

JEL Code Classifications: C32, E44, F62

UDC: 330.357

DOI: https://doi.org/10.17015/ejbe.2020.026.03

\footnotetext{
* Associate Professor, Department of Finance, University of Chittagong, Chittagong-4331, Bangladesh. Email: mostafacu2000@gmail.com 


\section{Introduction}

The stock market plays an important role in promoting the economic growth of a country. It offers an economy with some essential services, namely pooling and trading of risk, allocation of the fund by acquiring information ex-ante and accumulating and mobilization of savings. A developed stock market can provide and perform these functions more efficiently to the real sector. Innovation and development of new financial assets and services open up new opportunities for investors and savers, which leads to economic growth. Moreover, the development of the stock market may also be initiated through economic growth. The objective of this study is to investigate the dynamic relation between economic growth and stock market depth in the presence of three more macroeconomic indicators such as exchange rate, inflation and interest rate of Bangladesh.

Stock market depth is one of the most important forces which may influence and be influenced by economic growth. But stock market depth is quite a broad concept. Different empirical studies used different measures of stock market depth (see for example, Pradhan et al., 2019; Pradhan et al., 2015; Pradhan et al., 2013; Gries et al., 2009; Levine \& Zervos, 1998; Gregorio \& Guidotti, 1995). This study employs three indicators to represent the stock market depth, such as market capitalization, stock market turnover ratio and stock traded in the stock market.

Moreover, macroeconomic management is one of the key concerns that held a highly prominent place in the literature. Among the different macroeconomic factors, inflation, interest rate and exchange rate are the key indicators to stimulate economic stability and to promote economic development. The exact information of these macroeconomic variables is very much essential to effectively implement any economic policy to achieve sustainable economic growth. Therefore, a growing interest has emerged in recent years, investigating the dynamic interaction between macroeconomic indicators and economic growth in developing economies.

From the above discussion, it can be said that stock market depth and macroeconomic indicators play a significant role to promote economic growth. But the dynamic linkage between these variables is rather mixed. The indecisive nature of the findings may be due to use of a different set of economies and different periods of time. This empirical study employs an innovative econometric technique to explore the short-run and long-run relation between economic growth and stock market depth in the presence of three more macroeconomic indicators such as exchange rate, inflation and interest rate of Bangladesh.

The rest of this study is structured as follows. The literature review is depicted in section 2. Research hypotheses are articulated in section 3. Section 4 describes the variables, data and estimation strategy employed in this study. Empirical results and analysis are presented in section 5 , and section 6 concludes the paper. 
Dynamic relation between economic growth, stock market depth and some selected...

\section{Literature Review}

In this section, we review two sets of literature focusing on the granger causality between Stock market depth and economic growth and macroeconomic indicators and economic growth.

\subsection{Causality Between Stock Market Depth and Economic Growth}

Many studies have been conducted to examine the relation between stock market depth and economic growth in the context of developed and emerging economies at a different time, but there is no consensus and conclusive findings of the directions and their relationship. Several empirical findings of major studies are reported in the following paragraphs.

Schumpeter (1911) is a pioneer in investigating the relationship between stock market depth and economic growth. His empirical research focused on the necessity of financial services in persuading economic growth and emphasized that financial intermediaries can actively encourage financial innovation and support future growth by influencing and funding productive investments.

Two possible hypotheses, namely supply-leading hypothesis and demand-following hypothesis proposed by Patrick (1966), are used to identify the possible patterns of a causal relation between stock market depth and economic growth. The supplyleading hypothesis assumes a unidirectional causality running from stock market depth to economic growth which implies that the development of a modern financial system increase in the financial resources and financial innovation and services which accelerate economic growth. A good number of empirical studies accept this hypothesis. For instance, Nieuwerbugh et al. (2006) identified that stock market depth promotes economic growth in Belgium. Abu-Bader and Abu-Qarn (2008) investigate the causal relationship between these two indicators for six MENA countries by employing the Toda-Yamamoto Granger Causality Approach and found strong support in favour of this hypothesis in five countries. Verma and Mahajan (2015) reported that around 8.63 per cent of economic growth changes through financial development in India. In a more recent study, Pradhan et al. (2019) investigate the long-run and short-run relationship between stock market depth and economic growth along with two other macroeconomic variables by using Panel VECM for ASEAN economies and found that stock market depth granger cause of economic growth in both long-run and short run. Similarly, Atje and Jovanovic (1993), King and Levine (1993 a,b), Caporale et al. (2004), Rousseau and Sylla (2005), Shahbaz et al. (2008), Colombage (2009), Kolapo and Adaramola (2012), among others support this hypothesis.

On the contrary, demand-following hypothesis claims the existence of unidirectional causal relationship from economic growth to the stock market depth which means that the advancement of the contemporary financial system and associated financial services is in response to the demand for these services by investors and savers in 
the real economy. Many researchers accept this hypothesis. For example, Chandavarkar (1992), Stiglitz (1994), Xu (2000), Ang and McKibbin (2007), Panopoulou (2009), Kar et al. (2011) are the supports among others of this hypothesis.

Besides the above two hypotheses, the third possible association is a combination of the supply-leading and demand-following hypotheses which is known as feedback hypothesis. The feedback hypothesis suggests that stock market depth and economic growth can provide accompaniment and strengthen each other. This assertion supports the bidirectional causality, which implies that stock market depth is essential to economic growth and economic growth promotes the demand for financial services. Supporters of this hypothesis are Luintel and Khan (1999), Darrat et al. (2006), Hondroyiannis et al. (2005), Rashid (2008), Cheng (2012).

\subsection{Causality Between Macroeconomic Indicators and Economic Growth}

In this section, we examine the pattern of a causal relationship between economic growth and three selected macroeconomic variables, namely exchange rate, inflation and interest rate. Earlier empirical studies have failed to resolve the issue of causality between economic growth and macroeconomic forces. They document three possible causal relationships.

First, many empirical studies reported unidirectional causal relationship running from macroeconomic indicators to economic growth which is popularly known as a supply-leading hypothesis. Supporters of this hypothesis are Darrat (1999), Pradhan et al. (2013), Semuel and Nurina (2015), Otieno and Wepukhulu (2019), Chowdhury et al. (2019).

Second, another relationship believes the existence of unidirectional linkage from economic growth to macroeconomic variables. This proposition is termed as a demand-following hypothesis. Among many others, Ball and Moffitt (2001), Kiley (2003), Dew-Becker and Gordon (2005), Filis (2010), Kim et al. (2013) accept this hypothesis.

Finally, a few empirical studies reported two-way (i.e., bidirectional) causal relationship between economic growth and any one of the selected macroeconomic forces, which is described as the feedback hypothesis. The empirical researches that provide acceptance of this proposition are Baillie et al. (1996), Andres and Hernando (1997), Precious and Makhetha-Kosi (2014) and Alavinasab (2016), among others.

\section{Research Hypotheses}

We test the following six research hypotheses:

$\mathrm{H}_{1 \mathrm{~A}, \mathrm{~B}}$ : Stock market depth (such as market capitalization, stock market turnover ratio and stocks traded) Granger-cause economic growth and vice versa. 
Dynamic relation between economic growth, stock market depth and some selected...

$\mathrm{H}_{2 \mathrm{~A}} \mathrm{~B}$ : Macroeconomic variables (such as exchange rate, inflation and interest rate) Granger-cause economic growth and vice versa.

$\mathrm{H}_{3 \mathrm{~A}, \mathrm{~B}}$ : Macroeconomic variables (such as exchange rate, inflation and interest rate) Granger-cause Stock market depth and vice versa.

$\mathrm{H}_{4 \mathrm{~A}, \mathrm{~B}}$ : Exchange rate Granger-cause inflation and vice versa.

$\mathrm{H}_{5 \mathrm{~A}, \mathrm{~B}}$ : Exchange rate Granger-cause interest rate and vice versa.

$\mathrm{H}_{6 \mathrm{~A}, \mathrm{~B}}$ : Inflation Granger-cause interest rate and vice versa.

\section{Variables, Data and Estimation Strategy}

\subsection{Data and Variables}

This study utilized annual time series data covering from 1995 to 2018 . The data retrieved from the World Development Indicators (WDI) database of World Bank and Monthly Economic Trends (a monthly bulletin of Bangladesh Bank (BB), published by Statistic Department, Bangladesh Bank). If any time series data were missing, then this study uses the simple average of the data of the previous two years.

Different empirical studies used a different measure of stock market depth (see, for example, Pradhan et al., 2019; Pradhan et al., 2015; Pradhan et al., 2013; Gries et al., 2009; Levine \& Zervos, 1998; Gregorio \& Guidotti, 1995). Following the study of Pradhan et al. 2015, this study utilized three indicators to represent the stock market depth (SMD), such as market capitalization (MAC), stock market turnover ratio (STU) and stock traded in the stock market (STA). We also use GDP as a proxy of real per capita economic growth, the exchange rate (EX), inflation rate (INF) and interest rate (INT). These variables are defined in Table 1.

\section{Table 1. Definition and Sources of Variables}

\begin{tabular}{clc}
\hline Variable & \multicolumn{1}{c}{ Definition } & Source \\
\hline GDP & $\begin{array}{l}\text { The annual percentage growth rate of GDP per capita. This is the } \\
\text { measure of economic growth used in this study. }\end{array}$ & WDI \\
\hline MAC & $\begin{array}{l}\text { Market capitalization (also known as market value) is the share } \\
\text { price times the number of shares outstanding for listed domestic } \\
\text { companies. }\end{array}$ & WDI \\
\hline TUR & $\begin{array}{l}\text { Turnover ratio is the value of domestic shares traded divided by } \\
\text { their market capitalization. }\end{array}$ & BB \\
\hline TRA & Stocks traded; the total value is measured as a percentage of GDP. & WDI \\
\hline EX & $\begin{array}{l}\text { Official exchange rate refers to the exchange rate determined by } \\
\text { national authorities. It is calculated as an annual average based on } \\
\text { monthly averages (local currency units relative to the USD). }\end{array}$ & WDI \\
\hline INF & $\begin{array}{l}\text { Inflation, as measured by the consumer price index, reflects the } \\
\text { annual percentage change in the cost to the average consumer of } \\
\text { acquiring a basket of goods and services. }\end{array}$ & WDI \\
\hline INT & $\begin{array}{l}\text { Real interest rate is the lending interest rate adjusted for inflation } \\
\text { as measured by the GDP deflator. }\end{array}$ & WDI \\
\hline
\end{tabular}




\subsection{Estimation Strategy}

Since this study employs three measures of stock market depth (MAC/TUR/TRA), three models are considered to analyze the dynamic relation between economic growth (GDP), stock market depth (SMD) and three selected macroeconomic variables such as exchange rate (EX), inflation (INF) and interest rate (INT) of Bangladesh. Each of the models applies a different indicator of stock market depth. Model 1 comprises of GDP, MAC, EX, INF and INT; Model 2 includes GDP, TUR, EX, INF and INT and Model 3 consist of GDP, TRA, EX, INF and INT to examine the dynamic relations among the selected variables.

This study uses three steps estimation process to analyze the data. First, Unit root test is utilized to determine the nature of stationarity of time series data. Cointegration test is used in the second stage to determine whether there is any longrun relationships exist among the selected variables. Finally, a VAR model is employed to determine the direction of causality between the variables. These three techniques of analyzing the data are explained in brief below.

\subsubsection{Unit Root Rest}

Since, almost all of the economic and financial time series data are non-stationary at level (Nelson \& Plosser, 1982; Hill et al., 2001), examine the stationarity of such data is essential to ensure trustworthy estimate of VAR model. This study uses Augmented Dickey-Fuller (ADF, 1981) and Philips-Perron (PP, 1988) unit root test to check the stationarity of our data series. ADF and PP test hypothesized the existence of unit root in the series. Unit root test can also identify the order of integration between the time series data. Since these two units of root test techniques are widely used in different empirical analysis, we do not provide detail of these two techniques to save the space.

\subsubsection{Co-integration Test}

Co-integration test is applied to identify the long-run equilibrium relationship between economic growth (GDP), stock market depth (SMD) and three selected macroeconomic variables such as exchange rate (EX), inflation (INF) and interest rate (INT) of Bangladesh. Since Johansen procedure (Johansen, 1988, 1991; Johansen \& Juselius, 1990) can be applied in the multi-equation framework and detect more than one co-integrating vectors, this study applied Johansen method to verify whether a co-integrating relationship exists in the time series data.

The existence of the co-integrating vector can be identified by the trace test statistic and maximum Eigen-value test statistic, which are constructed in the following structure:

$\lambda_{\text {trace }}=-T \sum_{\mathrm{i}=\mathrm{r}+1}^{\mathrm{n}} \operatorname{In}\left(1-\lambda_{i}\right)$ and $\lambda_{\max }=-T \operatorname{In}\left(1-\lambda_{r+1}\right)$

Where $T$ denotes the number of observation and $\lambda$ represents the Eigen-value. 
Dynamic relation between economic growth, stock market depth and some selected...

Trace statistics tests the null hypothesis of at most $r$ cointegrating vectors against the $r$ or more cointegrating relations in the alternative hypothesis whereas Max Eigen-value test hypothesized at most $r$ co-integrating relation against the alternative of $r+1$. If we detect co-integration between the economic variables, we move forward to verify for the direction of causality between them.

\subsubsection{Vector Error Correction Model (VECM) Granger Causality Test}

Granger causality test is used to determine whether one variable is forecasted by another variable. This study employs Granger causality test to determine the direction of causality between the economic variables.

Johansen approach follows Vector Autoregressive (VAR) model and can be formulated in the following error correction form:

$D G D P_{t}=\Omega_{G D P}+\sum_{k=1}^{P_{1}} \alpha_{G D P k} D G D P_{t-k}+\sum_{k=1}^{P_{2}} \beta_{G D P k} D S M D_{t-k}+$

$\sum_{k=1}^{P_{3}} \delta_{G D P k} D E X_{t-k}+\sum_{k=1}^{P_{4}} \lambda_{G D P k} D I N F_{t-k}+\sum_{k=1}^{P_{5}} \pi_{G D P k} D I N T_{t-k}+$

$\omega_{G D P} \mathrm{ECT}_{G D P t-1}+\varepsilon_{G D P t}$

$H_{0}: \beta_{G D P k}=0 ; \delta_{G D P k}=0 ; \lambda_{G D P k}=0 ; \pi_{G D P k}=0 ; \omega_{G D P}=0$ for $\mathrm{k}=1, \ldots P_{1}$ to $P_{5}$

$H_{A}: \beta_{G D P k} \neq 0 ; \delta_{G D P k} \neq 0 ; \lambda_{G D P k} \neq 0 ; \pi_{G D P k} \neq 0 ; \omega_{G D P} \neq 0$ for at least one $\mathrm{k}$

$D S M D_{t}=\Omega_{S M D}+\sum_{k=1}^{P_{1}} \alpha_{S M D k} D S M D_{t-k}+\sum_{k=1}^{P_{2}} \beta_{S M D k} D G D P_{t-k}+$

$\sum_{k=1}^{P_{3}} \delta_{S M D k} D E X_{t-k}+\sum_{k=1}^{P_{4}} \lambda_{S M D k} D_{I N F_{t-k}}+\sum_{k=1}^{P_{5}} \pi_{S M D k} D I N T_{t-k}+$

$\omega_{S M D} \mathrm{ECT}_{S M D t-1}+\varepsilon_{S M D t}$

$H_{0}: \beta_{S M D k}=0 ; \delta_{S M D k}=0 ; \lambda_{S M D k}=0 ; \pi_{S M D k}=0 ; \omega_{S M D}=0$ for $\mathrm{k}=1, \ldots P_{1}$ to $P_{5}$

$H_{A}: \beta_{S M D k} \neq 0 ; \delta_{S M D k} \neq 0 ; \lambda_{S M D k} \neq 0 ; \pi_{S M D k} \neq 0 ; \omega_{S M D} \neq 0$ for at least one $\mathrm{k}$

$D E X_{t}=\Omega_{E X}+\sum_{k=1}^{P_{1}} \alpha_{E X k} D E X_{t-k}+\sum_{k=1}^{P_{2}} \beta_{E X k} D G D P_{t-k}+\sum_{k=1}^{P_{3}} \delta_{E X k} D S M D_{t-k}+$

$\sum_{k=1}^{P_{4}} \lambda_{E X k} D I N F_{t-k}+\sum_{k=1}^{P_{5}} \pi_{E X k} D_{I N T_{t-k}}+\omega_{E X} \mathrm{ECT}_{E X t-1}+\varepsilon_{E X t}$

$H_{0}: \beta_{E X k}=0 ; \delta_{E X k}=0 ; \lambda_{E X k}=0 ; \pi_{E X k}=0 ; \omega_{E X}=0$ for $\mathrm{k}=1, \ldots P_{1}$ to $P_{5}$

$H_{A}: \beta_{E X k} \neq 0 ; \delta_{E X k} \neq 0 ; \lambda_{E X k} \neq 0 ; \pi_{E X k} \neq 0 ; \omega_{E X} \neq 0$ for at least one $\mathrm{k}$

$D I N F_{t}=\Omega_{I N F}+\sum_{k=1}^{P_{1}} \alpha_{I N F k} D I N F_{t-k}+\sum_{k=1}^{P_{2}} \beta_{I N F k} D G D P_{t-k}+$

$\sum_{k=1}^{P_{3}} \delta_{I N F k} D S M D_{t-k}+\sum_{k=1}^{P_{4}} \lambda_{I N F k} D E X_{t-k}+\sum_{k=1}^{P_{5}} \pi_{I N F k} D I N T_{t-k}+$

$\omega_{I N F} \mathrm{ECT}_{I N F t-1}+\varepsilon_{I N F t}$

$H_{0}: \beta_{I N F K}=0 ; \delta_{I N F k}=0 ; \lambda_{I N F k}=0 ; \pi_{I N F k}=0 ; \omega_{I N F}=0$ for $\mathrm{k}=1, \ldots P_{1}$ to $P_{5}$

$H_{A}: \beta_{I N F k} \neq 0 ; \delta_{I N F k} \neq 0 ; \lambda_{I N F k} \neq 0 ; \pi_{I N F k} \neq 0 ; \omega_{I N F} \neq 0$ for at least one $\mathrm{k}$

$D I N T_{t}=\Omega_{I N T}+\sum_{k=1}^{P_{1}} \alpha_{I N T k} D I N T_{t-k}+\sum_{k=1}^{P_{2}} \beta_{I N T k} D G D P_{t-k}+$

$\sum_{k=1}^{P_{3}} \delta_{I N T k} D S M D_{t-k}+\sum_{k=1}^{P_{4}} \lambda_{I N T k} D E X_{t-k}+\sum_{k=1}^{P_{5}} \pi_{I N T k} D I N F_{t-k}+$

$\omega_{I N T} \mathrm{ECT}_{I N T t-1}+\varepsilon_{I N T t}$ 
$H_{0}: \beta_{I N T K}=0 ; \delta_{I N T k}=0 ; \lambda_{I N T k}=0 ; \pi_{I N T k}=0 ; \omega_{I N T}=0$ for $\mathrm{k}=1, \ldots P_{1}$ to $P_{5}$ $H_{A}: \beta_{I N T K} \neq 0 ; \delta_{I N T K} \neq 0 ; \lambda_{I N T k} \neq 0 ; \pi_{I N T K} \neq 0 ; \omega_{I N T} \neq 0$ for at least one $\mathrm{k}$ Where, $D$ represents the first difference of the variables;

Lag lengths are denoted in $\mathrm{P}_{1}, \mathrm{P}_{2}, \mathrm{P}_{3}, \mathrm{P}_{4}$ and $\mathrm{P}_{5}$;

$t$ represents the year;

$\varepsilon_{t}$ is a normally-distributed random-error term for all $\mathrm{i}$ and $\mathrm{t}$ with a zero mean and a finite heterogeneous variance

\section{Empirical Result and Analysis}

This study uses the secondary annual time series data of 1995 to 2018 to explore the dynamic relation between economic growth (GDP), stock market depth (SMD) and three selected macroeconomic variables such as exchange rate (EX), inflation (INF) and interest rate (INT) of Bangladesh. Some sophisticated and powerful econometrics techniques are employed to discover the relationships and their results and interpretations are reported in the following subsections.

\subsection{Stationarity Test}

To avoid the spurious correlation of the time series data, it is essential to test the stationarity of the data before carrying out any empirical analysis. This study uses ADF and PP test to discover the stationarity of each of the series. The results of unit root tests are reported in Table 2 . The results accept the null hypothesis of having a unit root at level, but it rejects the same at first difference which clearly evident that the financial variables become stationary at first difference. Thus the variables are integrated at order one, I(1).

\subsection{Co-integration Test}

Johansen and Juselius (1990) test of co-integration is employed to discover the number of co-integrating relationships between variables. For this purpose, we use both Trace and Maximum Eigen-value test statistics. The results of the co-integration test are documented in Table 3 for Model 1, Model 2 and Model 3. From Table 3 we see that both trace and Maximum Eigen-vale test statistics suggest one cointegrating vector for Model 1 and Model 2, whereas for Model 3 both test statistics detect two co-integrating vectors. Therefore, one co-integrating vector is used for model 1 and Model 2 and two co-integrating vectors are employed for Model 3 to discover the dynamic relation between economic growth (GDP), stock market depth (SMD) and three selected macroeconomic variables such as exchange rate (EX), inflation (INF) and interest rate (INT) of Bangladesh. 
Dynamic relation between economic growth, stock market depth and some selected...

Table 2. Unit Root Tests

\begin{tabular}{|c|c|c|c|c|c|c|}
\hline \multirow[t]{2}{*}{ Variables } & \multicolumn{3}{|c|}{$\begin{array}{l}\text { Augmented Dickey Fuller (ADF)Test } \\
\text { Statistic }\end{array}$} & \multicolumn{3}{|c|}{ Phillips-Perron(PP) Test Statistic } \\
\hline & Constant & $\begin{array}{l}\text { Constant } \\
\text { \& Trend }\end{array}$ & None & Constant & $\begin{array}{l}\text { Constant } \\
\text { \& Trend }\end{array}$ & None \\
\hline GNP & -0.87 & -3.04 & 1.07 & -0.93 & -2.45 & 1.13 \\
\hline DGNP & $-4.14 * * *$ & $-4.04 * *$ & $-3.88 * * *$ & $-4.13 * * *$ & $-4.00 * *$ & $-3.89 * * *$ \\
\hline MAC & -1.45 & -2.95 & -0.55 & -1.45 & -3.05 & -0.49 \\
\hline DMAC & $-5.99 * * *$ & $-5.78 * * *$ & $-6.02 * * *$ & $-5.97 * * *$ & $-5.77 * * *$ & $-5.91 * * *$ \\
\hline TUR & -1.28 & -2.01 & -1.09 & -1.37 & -2.95 & -1.03 \\
\hline DTUR & $-7.02 * * *$ & $-6.90 * * *$ & $-7.22 * * *$ & $-5.67 * * *$ & $-5.47 * * *$ & $-5.90 * * *$ \\
\hline TRA & -1.84 & -1.76 & -0.43 & -1.84 & -1.76 & -0.43 \\
\hline DTRA & $-3.08 * *$ & -3.13 & $-3.16 * * *$ & $-3.08 * *$ & -3.13 & $-3.16 * * *$ \\
\hline EX & -2.56 & -2.76 & 3.22 & $-2.65^{*}$ & -1.99 & 3.15 \\
\hline DEX & $-4.07 * * *$ & $-4.77 * * *$ & $-2.72 * * *$ & $-3.96 * * *$ & $-5.46 * * *$ & $-2.65^{* *}$ \\
\hline INF & $-3.06 * *$ & -2.88 & -0.62 & $-3.07 * *$ & -2.91 & -0.44 \\
\hline DINF & $-5.79 * * *$ & $-5.59 * * *$ & $-5.97 * * *$ & $-8.29 * * *$ & $-9.15 * * *$ & $-8.59 * * *$ \\
\hline INT & -2.05 & -2.20 & -1.27 & -1.37 & -1.64 & -1.16 \\
\hline DINT & $-3.29 * *$ & -3.21 & $-3.22 * * *$ & $-3.29 * *$ & -3.21 & $-3.21 * * *$ \\
\hline \multicolumn{7}{|c|}{ Critical Values (for first difference variables) } \\
\hline At $1 \%$ & -3.79 & -4.47 & -2.68 & -3.79 & -4.47 & -2.68 \\
\hline At $5 \%$ & -3.01 & -3.65 & -1.96 & -3.01 & -3.65 & -1.96 \\
\hline At $10 \%$ & -2.65 & -3.26 & -1.61 & -2.65 & -3.26 & -1.61 \\
\hline
\end{tabular}

Note: $D$ represents the first difference of the variable. The suitable lag length (for ADF test statistics) was determined by using AIC. For PP test statistics, bandwidths were selected by taking Newey-West automatic recommendation following Bartlett Kernel. $*, * *, * * *$ indicates that test value(s) is significant at $10 \%, 5 \%$ and $1 \%$ level respectively.

\subsection{Long-run Causal Relation}

Table 4 exhibits the causal relationship between economic growth and its regressors (MAC, TUR, TRA, EX, INF and INT). When we use DGDP as a dependent variable, the lagged error-correct term is found statistically significant in all three models. This manifest that GDP tends to converge to its long-run equilibrium path in response to changes in its regressors. The significance of the lagged error-term coefficient in the DGDP equation in each of the three models authenticates the existence of long-run equilibrium relationship between economic growth and its causal factors. So, we can conclude that economic growth is influenced by various measures of stock market depth (MAC/TUR/TRA), exchange rate, inflation, and lending interest rate in the long run.

The results of the study evident that if there is any shock in the long-run equilibrium relationship between the selected economic determinants, then economic growth will respond to correct this shock. ECT-1 is found statistically significant at $1 \%$ level for all the three measure of stock market depth. 
Mostafa ALI

Table 3. Unrestricted Co-integration Rank Test

\begin{tabular}{|c|c|c|c|c|c|c|c|}
\hline \multicolumn{8}{|c|}{ Model 1: GDP, MAC, EX, INF, INT } \\
\hline \multirow[b]{2}{*}{$\begin{array}{l}\text { Hypothesized } \\
\text { No. of CE(s) }\end{array}$} & \multirow[b]{2}{*}{$\begin{array}{l}\text { Eigen } \\
\text { value }\end{array}$} & \multicolumn{2}{|c|}{ Trace Test } & \multirow[b]{2}{*}{ Prob.** } & \multicolumn{2}{|c|}{ Max-Eigen Test } & \multirow[b]{2}{*}{ Prob.** } \\
\hline & & $\begin{array}{l}\text { Trace } \\
\text { Statistic }\end{array}$ & $\begin{array}{l}\text { Critical } \\
\text { Value at } \\
5 \% \text { level }\end{array}$ & & $\begin{array}{l}\text { Max-Eigen } \\
\text { Statistic }\end{array}$ & $\begin{array}{l}\text { Critical } \\
\text { Value at } \\
5 \% \text { level }\end{array}$ & \\
\hline None * & 0.90 & 90.44 & 69.82 & 0.00 & 48.68 & 33.88 & 0.00 \\
\hline At most 1 & 0.71 & 41.76 & 47.86 & 0.17 & 25.94 & 27.58 & 0.08 \\
\hline At most 2 & 0.38 & 15.82 & 29.79 & 0.72 & 10.11 & 21.13 & 0.73 \\
\hline At most 3 & 0.22 & 5.72 & 15.49 & 0.73 & 5.15 & 14.26 & 0.72 \\
\hline At most 4 & 0.03 & 0.57 & 3.84 & 0.45 & 0.57 & 3.84 & 0.45 \\
\hline \multicolumn{8}{|c|}{ Model 2: GDP, TUR, EX, INF, INT } \\
\hline & & \multicolumn{2}{|c|}{ Trace Test } & \multicolumn{4}{|c|}{ Max-Eigen Test } \\
\hline $\begin{array}{l}\text { Hypothesized } \\
\text { No. of CE(s) }\end{array}$ & $\begin{array}{l}\text { Eigen } \\
\text { value }\end{array}$ & $\begin{array}{l}\text { Trace } \\
\text { Statistic }\end{array}$ & $\begin{array}{l}\text { Critical } \\
\text { Value at } \\
5 \% \text { level }\end{array}$ & Prob.** & $\begin{array}{l}\text { Max-Eigen } \\
\text { Statistic }\end{array}$ & $\begin{array}{l}\text { Critical } \\
\text { Value at } \\
5 \% \text { level }\end{array}$ & Prob.** \\
\hline None * & 0.90 & 98.81 & 69.82 & 0.00 & 48.46 & 33.88 & 0.00 \\
\hline At most 1 & 0.65 & 50.36 & 47.86 & 0.13 & 22.33 & 27.58 & 0.20 \\
\hline At most 2 & 0.63 & 28.03 & 29.79 & 0.08 & 20.82 & 21.13 & 0.06 \\
\hline At most 3 & 0.17 & 7.21 & 15.49 & 0.55 & 3.83 & 14.26 & 0.88 \\
\hline At most 4 & 0.15 & 3.39 & 3.84 & 0.07 & 3.39 & 3.84 & 0.07 \\
\hline \multicolumn{8}{|c|}{ Model 3: GDP, TRA, EX, INF, INT } \\
\hline & & \multicolumn{2}{|c|}{ Trace Test } & & \multicolumn{2}{|c|}{ Max-Eigen Test } & \\
\hline $\begin{array}{l}\text { Hypothesized } \\
\text { No. of CE(s) }\end{array}$ & $\begin{array}{l}\text { Eigen } \\
\text { value }\end{array}$ & $\begin{array}{l}\text { Trace } \\
\text { Statistic }\end{array}$ & $\begin{array}{l}\text { Critical } \\
\text { Value at } \\
5 \% \text { level }\end{array}$ & Prob. $^{* *}$ & $\begin{array}{l}\text { Max-Eigen } \\
\text { Statistic }\end{array}$ & $\begin{array}{l}\text { Critical } \\
\text { Value at } \\
5 \% \text { level }\end{array}$ & Prob.** \\
\hline None $*$ & 0.84 & 101.29 & 69.82 & 0.00 & 38.04 & 33.88 & 0.02 \\
\hline At most $1^{*}$ & 0.78 & 63.26 & 47.86 & 0.03 & 31.54 & 27.58 & 0.01 \\
\hline At most 2 & 0.62 & 31.73 & 29.79 & 0.07 & 20.13 & 21.13 & 0.07 \\
\hline At most 3 & 0.39 & 11.60 & 15.49 & 0.17 & 10.68 & 14.26 & 0.17 \\
\hline At most 4 & 0.04 & 0.92 & 3.84 & 0.34 & 0.92 & 3.84 & 0.34 \\
\hline
\end{tabular}

Note: ${ }^{*}$ represents the rejection of the null hypothesis of no co-integration at 0.05 significance level. ${ }^{* *}$ denotes $\mathrm{p}$ values are taken from Mackinnon-Haug-Michelis (1999) table. Trace statistic and Max-Eigen statistic suggest two (2) cointegrating vectors.

Among the three measures of stock market depth, the highest error-correction term coefficient is reported for TUR, which is 0.7993 . This indicates that for any deviation in the long-run equilibrium relationship, around $80 \%$ deviations will be adjusted in the next year. For other measures of stock market depth such as MAC and TRA, 71\% deviations for TRA and about 32\% for MAC will be corrected in the following year.

The ECT-1 in the DMAC, DTUR, or DTRA is not statistically significant in any of the three models. Therefore, stock market depth indicators demonstrate no evidence of correcting any shocks from the long-run equilibrium. This is also true for DEX, DINF and DINT in the VECM model. Hence, there is no long-run causal relationship running from the independent variables to the dependent variable. 
Dynamic relation between economic growth, stock market depth and some selected...

Table 4. Granger Causality test

\begin{tabular}{|c|c|c|c|c|c|c|}
\hline \multirow{2}{*}{$\begin{array}{l}\text { Dependent } \\
\text { Variable }\end{array}$} & \multicolumn{5}{|c|}{ F-statistics } & \multirow{2}{*}{$\begin{array}{l}\text { Coefficient of } \\
\text { ECT }_{-1}\end{array}$} \\
\hline & \multicolumn{5}{|c|}{ Independent variables } & \\
\hline \multicolumn{7}{|c|}{ Model 1: VECM with GDP, MAC, EX, INF, INT } \\
\hline & DGDP & DMAC & DEX & DINF & DINT & \\
\hline DGDP & --- & $\begin{array}{l}2.66^{*} \\
{[0.08]}\end{array}$ & $\begin{array}{c}0.41 \\
{[0.53]} \\
\end{array}$ & $\begin{array}{l}3.62^{*} \\
{[0.08]}\end{array}$ & $\begin{array}{l}2.91^{*} \\
{[0.09]}\end{array}$ & $\begin{array}{c}-0.32 * * * \\
(-3.62) \\
\end{array}$ \\
\hline DMAC & $\begin{array}{l}5.92 * * \\
{[0.05]}\end{array}$ & --- & $\begin{array}{l}4.01^{*} \\
{[0.10]}\end{array}$ & $\begin{array}{c}1.26 \\
{[0.28]}\end{array}$ & $\begin{array}{l}6.26 * * \\
{[0.05]}\end{array}$ & $\begin{array}{c}0.95 \\
(2.53) \\
\end{array}$ \\
\hline DEX & $\begin{array}{c}0.02 \\
{[0.89]}\end{array}$ & $\begin{array}{l}3.46^{*} \\
{[0.09]}\end{array}$ & --- & $\begin{array}{c}1.52 \\
{[0.24]}\end{array}$ & $\begin{array}{l}3.59^{*} \\
{[0.08]}\end{array}$ & $\begin{array}{c}0.62 \\
(3.12)\end{array}$ \\
\hline DINF & $\begin{array}{l}5.23 * * \\
{[0.04]}\end{array}$ & $\begin{array}{l}4.54^{*} \\
{[0.07]}\end{array}$ & $\begin{array}{c}0.14 \\
{[0.71]}\end{array}$ & --- & $\begin{array}{l}3.39 * \\
{[0.09]}\end{array}$ & $\begin{array}{c}0.04 \\
(0.45)\end{array}$ \\
\hline DINT & $\begin{array}{l}4.05^{* *} \\
{[0.05]}\end{array}$ & $\begin{array}{c}0.79 \\
{[0.39]}\end{array}$ & $\begin{array}{l}3.64^{*} \\
{[0.08]}\end{array}$ & $\begin{array}{l}3.94^{*} \\
{[0.07]}\end{array}$ & --- & $\begin{array}{c}0.07 \\
(0.59)\end{array}$ \\
\hline \multicolumn{7}{|c|}{ Model 2: VECM with GDP, TUR, EX, INF, INT } \\
\hline & DGDP & DTUR & DEX & DINF & DINT & $\mathrm{ECT}_{-1}$ \\
\hline DGDP & --- & $\begin{array}{l}1.168 \\
{[0.29]}\end{array}$ & $\begin{array}{l}3.03^{*} \\
{[0.06]}\end{array}$ & $\begin{array}{c}0.89 \\
{[0.73]}\end{array}$ & $\begin{array}{l}4.10 * * \\
{[0.03]}\end{array}$ & $\begin{array}{c}-0.799 * * * \\
(-3.85)\end{array}$ \\
\hline DTUR & $\begin{array}{l}3.19^{*} \\
{[0.09]}\end{array}$ & --- & $\begin{array}{c}0.10 \\
{[0.75]}\end{array}$ & $\begin{array}{c}1.15 \\
{[0.30]}\end{array}$ & $\begin{array}{c}2.26 \\
{[0.16]} \\
\end{array}$ & $\begin{array}{c}0.16 \\
(1.01) \\
\end{array}$ \\
\hline DEX & $\begin{array}{l}3.32^{*} \\
{[0.09]}\end{array}$ & $\begin{array}{c}0.89 \\
{[0.36]}\end{array}$ & --- & $\begin{array}{l}4.38^{*} \\
{[0.06]}\end{array}$ & $\begin{array}{c}0.85 \\
{[0.37]}\end{array}$ & $\begin{array}{l}-0.26 \\
(-1.55)\end{array}$ \\
\hline DINF & $\begin{array}{l}3.17^{* *} \\
{[0.03]}\end{array}$ & $\begin{array}{l}1.036 \\
{[0.16]}\end{array}$ & $\begin{array}{l}2.06^{*} \\
{[0.07]}\end{array}$ & --- & $\begin{array}{c}0.20 \\
{[0.66]}\end{array}$ & $\begin{array}{l}-0.06 \\
(-0.82)\end{array}$ \\
\hline DINT & $\begin{array}{l}3.43^{*} \\
{[0.09]}\end{array}$ & $\begin{array}{c}0.097 \\
{[0.76]}\end{array}$ & $\begin{array}{c}3.21 * \\
{[0.096]}\end{array}$ & $\begin{array}{l}6.09 * * \\
{[0.03]}\end{array}$ & --- & $\begin{array}{c}0.03 \\
(2.29)\end{array}$ \\
\hline \multicolumn{7}{|c|}{ Model 3: VECM with GDP, TRA, EX, INF, INT } \\
\hline & DGDP & DTRA & DEX & DINF & DINT & $\mathrm{ECT}_{-1}$ \\
\hline DGDP & --- & $\begin{array}{c}5.49 * * * \\
{[0.01]}\end{array}$ & $\begin{array}{c}1.34 \\
{[0.27]}\end{array}$ & $\begin{array}{l}3.04^{*} \\
{[0.06]}\end{array}$ & $\begin{array}{c}0.42 \\
{[0.53]}\end{array}$ & $\begin{array}{c}-0.71 * * * \\
(-2.65)\end{array}$ \\
\hline DTRA & $\begin{array}{l}3.33 * * \\
{[0.03]}\end{array}$ & --- & $\begin{array}{l}2.03^{*} \\
{[0.08]}\end{array}$ & $\begin{array}{l}1.98^{*} \\
{[0.09]}\end{array}$ & $\begin{array}{c}0.62 \\
{[0.45]}\end{array}$ & $\begin{array}{c}-0.02 \\
(-0.10)\end{array}$ \\
\hline DEX & $\begin{array}{l}4.03 * \\
{[0.07]}\end{array}$ & $\begin{array}{l}3.17^{*} \\
{[0.08]}\end{array}$ & --- & $\begin{array}{l}2.67^{*} \\
{[0.09]}\end{array}$ & $\begin{array}{c}0.02 \\
{[0.89]}\end{array}$ & $\begin{array}{c}0.55 \\
(2.21) \\
\end{array}$ \\
\hline DINF & $\begin{array}{l}3.01^{*} \\
{[0.08]}\end{array}$ & $\begin{array}{l}4.11^{* *} \\
{[0.04]}\end{array}$ & $\begin{array}{c}0.86 \\
{[0.37]}\end{array}$ & --- & $\begin{array}{c}0.02 \\
{[0.89]}\end{array}$ & $\begin{array}{c}1.58^{* * *} \\
(5.17)\end{array}$ \\
\hline DINT & $\begin{array}{l}3.93^{*} \\
{[0.08]}\end{array}$ & $\begin{array}{c}0.09 \\
{[0.77]}\end{array}$ & $\begin{array}{l}1.5765 \\
{[0.23]}\end{array}$ & $\begin{array}{l}4.11^{* *} \\
{[0.04]}\end{array}$ & --- & $\begin{array}{c}-0.03 \\
(-0.7237)\end{array}$ \\
\hline
\end{tabular}

Source: Author's own estimation.

Note: Variables are defined in Table 1. VECM: Vector Error Correction Model; ECT-1: lagged errorcorrection term. This study considers three indicators of stock market depth, namely MAC, TUR, and TRA. A different indicator is used in each model. $*, * *, * * *$ represent the test statistic is significant at $10 \%, 5 \%$ and $1 \%$ respectively. Values in square brackets represent probabilities for F-statistics, whereas values in parentheses represent t-statistics. Long-run causality is determined by the significance of the lagged ECT coefficient. 


\subsection{Short-run Causal Relation}

The previous section explains the long-run causality between the variables. In this section, our empirical study explores a wide continuum of a short-run causal relationship between chosen variables. The causal test statistics are reported in Table 4, and the results of causal relations are qualitatively summarized in Table 5.

In Model 1, a bidirectional causal relationship is found between market capitalization and economic growth, inflation and economic growth, lending interest rate and economic growth, market capitalization and exchange rate, lending interest rate and exchange rate and interest rate and inflation. In addition, we ascertain unidirectional causal relation running from market capitalization to inflation and lending interest rate to market capitalization.

In Model 2, this study uncovers the existence of bidirectional causality between exchange rate and economic growth, lending interest rate and economic growth and inflation and exchange rate. Moreover, we uncover unidirectional causality from economic growth to turn over ratio, economic growth to inflation, exchange rate to lending interest rate and inflation to the lending interest rate.

Table 5. Short-run Granger Causality Between Economic Growth, Stock Market Depth, Exchange Rate, Inflation and Interest Rate

\begin{tabular}{llll}
\hline Causal Relationships & \multicolumn{2}{l}{ The direction of relationships found in } \\
\cline { 2 - 4 } Tested in the Models & Model 1 & Model 2 & Model 3 \\
\hline SMD vs. GDP & MAC $\Leftrightarrow$ GDP & GDP $=>$ TUR & TRA $\Leftrightarrow$ GDP \\
\hline GDP vs. EX & NA & EX $\Leftrightarrow$ GDP & GDP $=>$ EX \\
\hline GDP vs. INF & INF $\Leftrightarrow$ GDP & GDP $=>$ INF & INF $\Leftrightarrow$ GDP \\
\hline GDP vs. INT & INT $\Leftrightarrow$ GDP & INT $\Leftrightarrow$ GDP & GDP $=>$ INT \\
\hline EX vs. SMD & EX $\Leftrightarrow$ MAC & NA & EX $\Leftrightarrow$ TRA \\
\hline INF vs. SMD & MAC $=>$ INF & NA & INF $\Leftrightarrow$ TRA \\
\hline INT vs. SMD & INT $=>$ MAC & NA & NA \\
\hline EX vs. INF & NA & INF $\Leftrightarrow$ EX & INF $=>$ EX \\
\hline EX vs. INT & INT $\Leftrightarrow$ EX & EX $=>$ INT & NA \\
\hline INF vs. INT & INT $\Leftrightarrow$ INF & INF $=>$ INT & INF $=>$ INT
\end{tabular}

Source: Author's own estimation.

Note: The causality is examined in the framework of VECM. $X \Leftrightarrow Y$ represents the bidirectional or feedback relationship whereas $X=>Y$ denotes the unidirectional relation running from $X$ to $Y$.

In model 3, we again reveal the presence of a bidirectional causal relationship between traded stock and economic growth, inflation and economic growth, exchange rate and traded stock and inflation and traded stock. Furthermore, we demonstrate one-way causal relation running from economic growth to exchange rate, economic growth to lending interest rate, inflation to exchange rate and inflation to lending interest rate. 
Dynamic relation between economic growth, stock market depth and some selected...

\subsection{Impulse Response Analysis}

10-year Generalized Impulse Response Functions (GIRFs) are estimated by using Cholesky decomposition method to detect the effect of a one-off shock to one of the innovations on the present and future values of the endogenous variables. The main advantage of using GIRFs is that the responses are unvarying to any re-ordering of the variables in the VECM (Pesaran \& Shin, 1998). Moreover, GIRFs do not impose orthogonality; it permits for a worthwhile explanation of the initial response of each variable to shocks to any other variables. We display three sets of GIRFs of the three models focus on the responses of economic growth, stock market depth (MAC/ TUR/ TRA), exchange rate, inflation and interest rate to their own and other shocks in figures 1, 2 and 3. Particularly, GIRFs stipulate how long and to what extent both stock market depth and other three macroeconomic indicators respond to changes in the economic growth of Bangladesh.
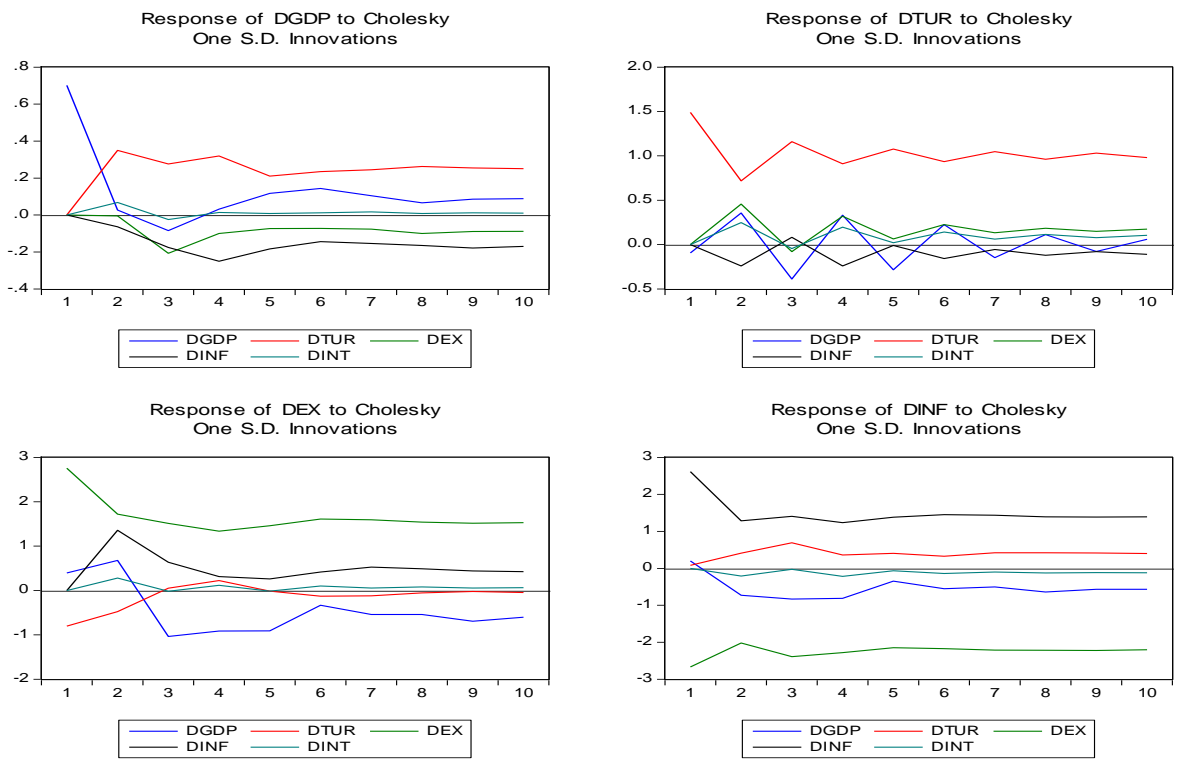

Response of DINT to Cholesky One S.D. Innovations

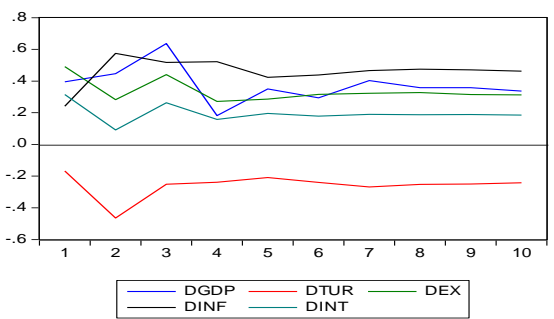

Figure 1. Generalized impulse functions for GDP, TUR, EX, INF, and INT 
Figure 1 of Model 1 depicts the response to Cholesky one standard deviation shock of economic growth, stock market capitalization and three other macroeconomic fundamentals over a horizon of 10 years. We find that in every case stock market capitalization demonstrate an initial cyclical response to an exogenous shock at varying extent. But, the responses of other variables to exogenous shocks stabilize in around 7 years.

Figure 2 and Figure 3 demonstrate the responses of all the variables to a one standard deviation shock in other variables for Model 2 and Model 3, respectively. Scrutinizing both figures, we find that the responses of all variables to an exogenous shock are almost identical to figure 1 of Model 1 . This evident that for three alternative measures of stock market depth, the responses of variables are almost indistinguishable.
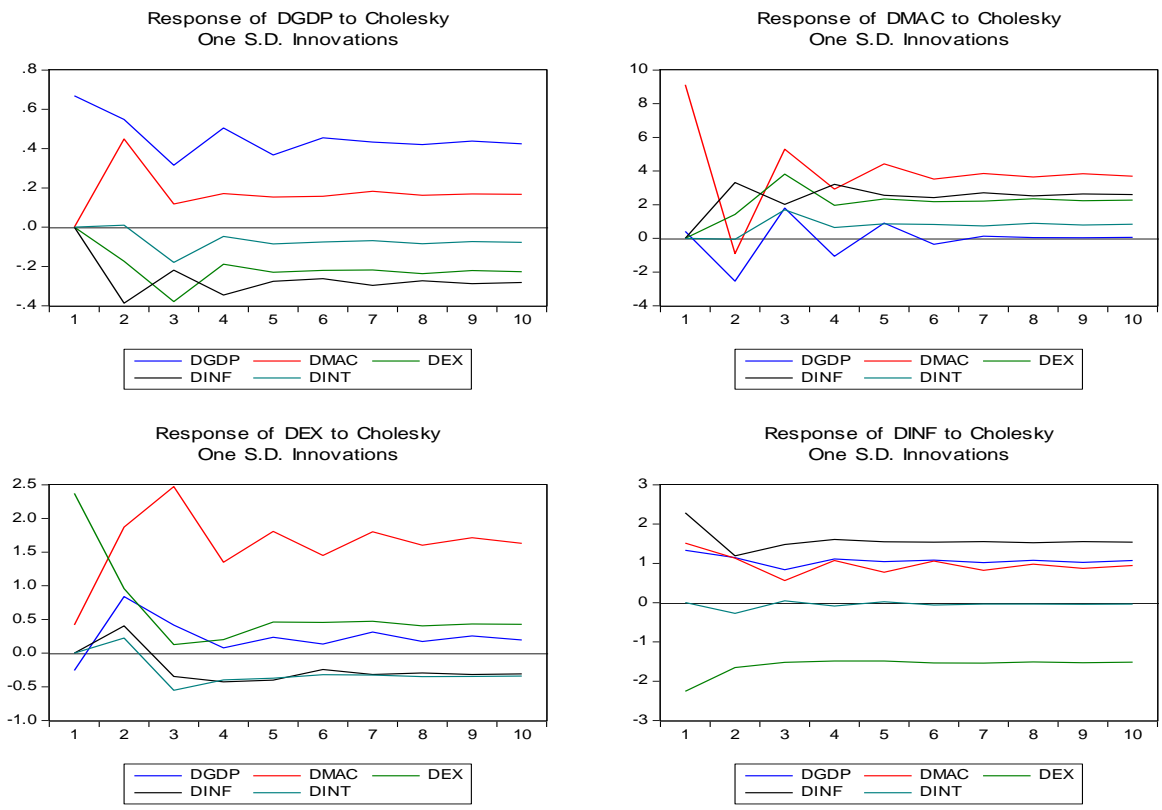

Response of DINT to Cholesky One S.D. Innovations

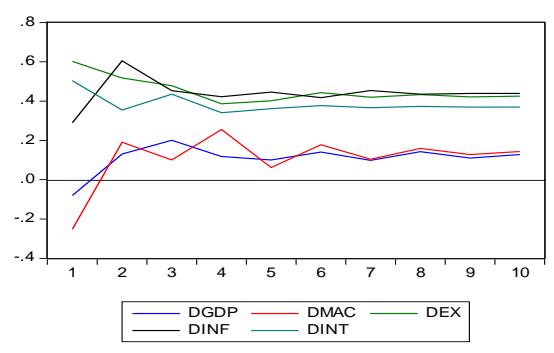

Figure 2. Generalized impulse functions for GDP, MAC, EX, INF, and INT 
Dynamic relation between economic growth, stock market depth and some selected...

Response of DGDP to Cholesky

One S.D. Innovations
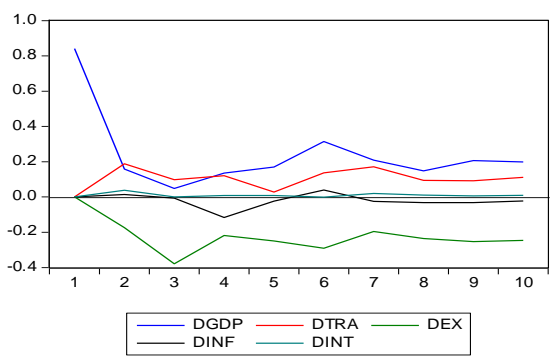

Response of DEX to Cholesky One S.D. Innovations
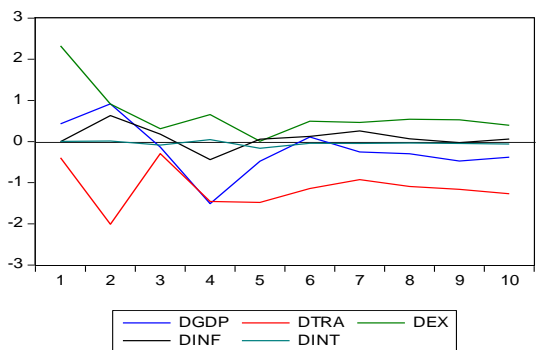

Response of DINT to Cholesky One S.D. Innovations

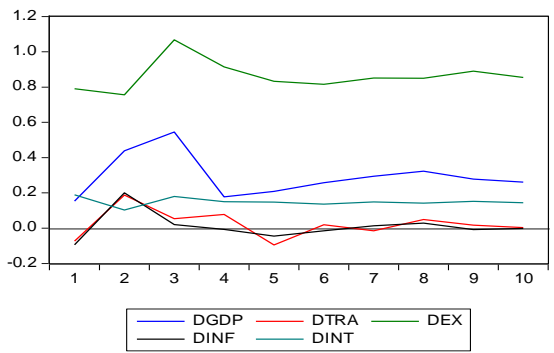

Response of DTRA to Cholesky

One S.D. Innovations

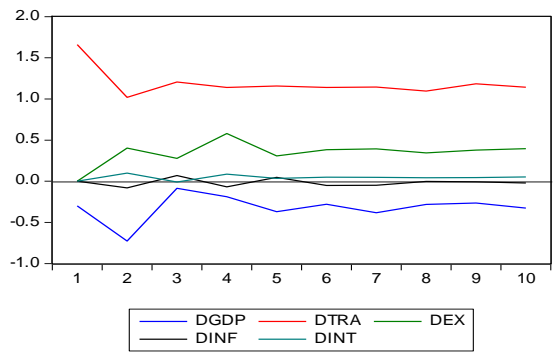

Response of DINF to Cholesky One S.D. Innovations

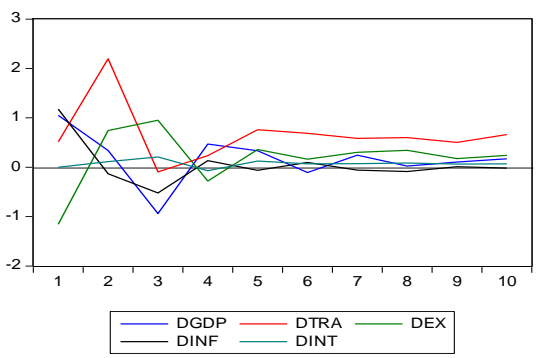

Figure 3. Generalized impulse functions for GDP, TRA, EX, INF, and INT

\section{Conclusion}

This paper investigates the dynamic interaction between economic growth and stock market depth along with the three other macroeconomic indicators such as exchange rate, interest rate and inflation which are closely related to each other. The concept of stock market depth is quite wide, and many researchers use different measures of stock market depth in their empirical studies; we consider three measures to represent stock market depth (SMD): market capitalization (MAC), stock market turnover ratio (STU) and stock traded in the stock market (STA). We employ Johansen and Juselius (1990) test of co-integration and Vector Error Correction 
Model (VECM) to discover the possible short-run and long-run causal relationship among the selected economic variables.

The results of the study show that the lagged error correction term of the economic growth is statistically significant in all three measures of stock market depth which give evidence that there is a general long-run equilibrium relationship between economic growth and its regressors. In other words, real economic growth responds to any shock in the long-run equilibrium linkage that is found to exist between the different measures of stock market depth and the other macroeconomic variables. But, in the short-run, we uncover a multifaceted network of causal links which provide a vague idea as to which of the three measure of stock market depth granger cause economic growth and other three indicators of the macro economy of Bangladesh. We find evidence of both unidirectional and mutual relations for the three different models. The finding of this empirical study accepts the supply-leading hypothesis, which implies that stock market depth and the other three macroeconomic indicators help accelerate economic growth in the long-run. In the short run, however, we find the evidence of unidirectional as well as mutual relationships between economic growth, stock market depth and other three macroeconomic indicators of Bangladesh.

In respect to policy implication, decision-makers of Bangladesh should promote longrun economic growth by encouraging stock market development in terms of both size and degree of sophistication and stabilizing macroeconomic environment. More particularly, stock market development can be accelerated not only make the stock market more accessible to the small companies that want to raise capital as well as for small investors but also make policies that guarantee the financial stability of stock market along with the macroeconomic environment of Bangladesh.

\section{References}

Abu-Bader, S., \& Abu-Qarn, A. S. (2008). Financial development and economic growth: empirical evidence from six MENA countries. Review of Development Economics, 12 (4), 803817. https://doi.org/10.1111/i.1467-9361.2008.00427.x

Alavinasab, S. M. (2016). Monetary policy and economic growth: a case study of Iran. International Journal of Economics, Commerce and Management, 4(3), 234-244.

Ang, J. B., \& McKibbin (2007). Financial liberalization, financial sector development and growth: Evidence from Malaysia. Journal of Development Economics, 84(1), 215-233. https://doi.org/10.1016/j.jdeveco.2006.11.006

Atje, R., \& Jovanovic, B. (1993). Stock markets and development. European Economic Review, 37(2-3), 632-640. https://doi.org/10.1016/0014-2921(93)90053-D

Ball, L., \& Moffitt, R. (2001). Productivity growth and the Phillips curve, NBER Working Paper No. 8421, National Bureau of Economic Research, Retrieved from http://www.nber.org/papers/w8421.pdf https://doi.org/10.3386/w8421

Caporale, G. M., Howells, G. M., \& Soliman, A. A. (2004). Stock markets development and economic growth: the causal linkage. Journal of Economic Development, 29(1), 33-50. Retrieved from http://www.jed.or.kr/full-text/29-1/02 J665 .PDF 
Dynamic relation between economic growth, stock market depth and some selected...

Chandavarkar, A. (1992). Of finance and development: neglected and unsettled questions. World Development, 20(1), 133-142. https://doi.org/10.1016/0305-750X(92)90142-1

Cheng, S. (2012). Substitution or complementary effects between banking and stock markets: Evidence from financial openness in Taiwan. Journal of International Financial Markets Institutions and Money, 22(3), 508-520. https://doi.org/10.1016/i.intfin.2012.01.007

Chowdhury, A H M. Y., Hamid, M. K., \&Akhi, R. A. (2019). Impact of macroeconomic variables on the economic growth: Bangladesh perspective. Information Management and Computer Science, 2(2), 19-22. https://doi.org/10.26480/imcs.02.2019.19.22

Colombage, S. R. N. (2009). Financial markets and economic performances: Empirical evidence from five industrialized economies. Research in International Business and Finance, 23, 339348. https://doi.org/10.1016/j.ribaf.2008.12.002

Darrat, A. F. (1999). Are financial deepening and economic growth causally related? Another look at the evidence. International Economic Journal, 13, 19-35. https://doi.org/10.1080/10168739900000002

Darrat, A. F., Elkhal, K., \& McCallum, B. (2006). Finance and macroeconomic performance: Some evidence from emerging markets. Emerging Markets Finance and Trade, 42(3), 5-28. https://doi.org/10.2753/REE1540-496X420301

Dew-Becker, I., \& Gordon, R. (2005). Where did the productivity growth go? Inflation dynamics and the distribution of income. NBER Working Paper No. 11482. National Bureau of Economic Research. Retrieved from http://www.nber.org/papers/w11842.pdf

Dickey, D. A., \& Fuller, W.A. (1981). Likelihood ratio statistics for autoregressive time series with a unit root. Econometrica, 49, 1057-1072. https://doi.org/10.2307/1912517

Filis, G. (2010). Macro economy, stock market and oil prices: Do meaningful relationships exist among their cyclical fluctuations? Energy Economics, 32(4), 877-886. https://doi.org/10.1016/i.eneco.2010.03.010

Gregorio, J. D., \& Guidotti, P. E. (1995). Financial development and economic growth. World Development, 23(3), 433-448. https://doi.org/10.1016/0305-750X(94)00132-I

Gries, T., Kraft, M., \& Meierrieks, D. (2009). Linkages between financial deepening, trade openness, and economic development: Causality evidence from Sub-Saharan Africa. World Development, 37(12), 1849-1860. https://doi.org/10.1016/j.worlddev.2009.05.008

Hill, R. C., Griffiths, W., \& Judge, G. (2001). Undergraduate Econometrics (2nd ed.). New York, USA: Wiley.

Hondroyiannis, G., Lolos, S. \& Papapetron, E. (2005). Financial market and economic growth in Greece, 1986-1999. Journal of International Financial Markets, Institutions and Money, 15(2), 173-178. https://doi.org/10.1016/i.intfin.2004.03.006

Johansen, S. (1988). Statistical analysis of co-integration vectors. Journal of Economic Dynamics and Control, 12(2-3), 231-254. https://doi.org/10.1016/0165-1889(88)90041-3

Johansen, S. (1991). Estimation and hypothesis testing of cointegrating vectors in Gaussian vector autoregressive models. Econometrica, 59, 1551-1580. https://doi.org/10.2307/2938278

Johansen, S., \& Juselius, K. (1990), Maximum likelihood estimation and inference on cointegration with application to the demand for money. Oxford Bulletin of Economics and Statistics, 52, 169-210. https://doi.org/10.1111/j.1468-0084.1990.mp52002003.x 
Kar, M., Nazlioglu, S., \& Agir, H. (2011). Financial development and economic growth nexus in the MENA countries: Bootstrap panel Granger causality analysis. Economic Modeling, 28(1-2), 685-693. https://doi.org/10.1016/i.econmod.2010.05.015

Kiley, M. (2003). Why is inflation low when productivity growth is high? Economic Inquiry, 41(3), 392-406. https://doi.org/10.1093/ei/cbg016

Kim, S., Lim, H., \& Park, D. (2013). Does productivity growth lower inflation in Korea. Applied Economics, 45(16), 2183-2190. https://doi.org/10.1080/00036846.2012.657352

King, R. G., \& Levine, R. (1993a). Finance and growth: Schumpeter might be right. Quarterly Journal of Economics, 108(3), 717- 738. https://doi.org/10.2307/2118406

King, R. G., \& Levine, R., (1993b). Finance, entrepreneurship and growth: theory and evidence. Journal of Monetary Economics, 32(3), 513- 542. https://doi.org/10.1016/03043932(93)90028-E

Levine, R., \& Zervos, S. (1998). Stock markets, banks and economic growth. The American Economic Review, 88(3), 537-558.

Luintel, K. B., \& Khan, M. (1999). A Quantitative Re-assessment of Finance-Growth Nexus: Evidence from a Multivariate VAR. Journal of Development Economics, 60(2), 381-405. https://doi.org/10.1016/S0304-3878(99)00045-0

Nelson, C. R., \& Plosser, C. I. (1982). Trends and random walk in macroeconomic time series. Journal of Monetary Economics, 10(2), 139-162. https://doi.org/10.1016/03043932(82)90012-5

Nieuwerbugh, S. V., Buelens, F., \& Cuyvers, L. (2006). Stock market development and economic growth in Belgium. Explorations in Economic History, 43(1), 13-38. https://doi.org/10.1016/i.eeh.2005.06.002

Otieno, O. G., \& Wepukhulu, J. M. (2019). Effect of macroeconomic factors on economic growth of Kenya. International Journal of Economics, 4(1), 43 - 67.

Panopoulou, E. (2009). Financial variables and euro area growth: A non-parametric causality analysis. Economic Modeling, 26(6), 1414-1419. https://doi.org/10.1016/j.econmod.2009.07.013

Patrick, H. T. (1966). Financial development and economic growth in underdeveloped countries. Economic Development and Cultural Change, 14(2), 174-189. http://dx.doi.org/10.1086/450153

Pesaran, H. H., \& Shin, Y. (1998). Generalized impulse response analysis in linear multivariate models. Economics Letters, 58(1), 17-29. https://doi.org/10.1016/S0165-1765(97)00214-0

Phillips, P. C. B., \& Perron, P. (1988). Testing for a unit root in time series regression. Biometrika, 75(2), 335-346. https://doi.org/10.2307/2336182

Pradhan, R. P., Arvin, M. B., \& Ghoshray, A. (2015). The dynamics of economic growth, oil prices, stock market depth, and other macroeconomic variables: Evidence from the G-20 countries. International Review of Financial Analysis, 39, 84-95. https://doi.org/10.1016/j.irfa.2015.03.006

Pradhan, R. P., Arvin, M. B., \& Hall, J. H. (2019). The nexus between economic growth, stock market depth, trade openness, and foreign direct investment: the case of ASEAN countries. The Singapore Economic Review, 64(3), 461-493. https://doi.org/10.1142/S0217590817500175 
Dynamic relation between economic growth, stock market depth and some selected...

Pradhan, R. P., Arvin, M. B., Bele, S., \& Shilpa, T. (2013). The impact of stock market development on inflation and economic growth of 16 Asian countries: A panel VAR approach. Applied Econometrics and International Development, 13(1), 203-220.

Pradhan, R.P., Mukhopadhyay, B., Gunashekar, A., Samadhan, B., \& Pandey, S. (2013). Financial development, social development, and economic growth: The causal nexus in Asia. Decision, 40, 69-83. https://doi.org/10.1007/s40622-013-0011-3

Precious, C. \& Makhetha-Kosi, P. (2014). Impact of Monetary Policy on Economic Growth: A Case Study of South Africa. Mediterranean Journal of Social Sciences, 5(15), 76-84. https://doi.org/10.5901/mjss.2014.v5n15p76

Rashid, A. (2008). Macroeconomic variables and stock market performance: Testing for dynamic linkages with a known structural break. Savings and Development, 32(1), 77-102.

Rousseau, P., \& Sylla, R. (2005). Emerging financial markets and early U.S. growth. Explorations of Economic History, 42, 1-26. https://doi.org/10.1016/i.eeh.2004.03.004

Schumpeter, J. A. (1911). The Theory of Economic Development; an Inquiry into Profits, Capital, Credit, Interest, and the Business Cycle, Translated by Opie, R. Harvard University Press, Cambridge.

Semuel, H., \& Nurina, S. (2015, February). Analysis of the effect of inflation, interest rates, and exchange rates on Gross Domestic Product (GDP) in Indonesia. Paper presented at the International Conference on Global Business, Economics, Finance and Social Sciences, Bangkok, Thailand. Retrieved from https://pdfs.semanticscholar.org/bc41/2ed3f7bae206a9efa0df3011a7651659c2f4.pdf

Shahbaz, M., Ahmed, N., \& Ali, L. (2008). Stock Market Development and Economic Growth: Ardl causality in Pakistan. International Research Journal of Finance and Economic Issues, 14, $183-195$.

Stiglitz, J., (1994, March). The role of the state in financial markets. In: Bruno, M., Pleskovic, B. (Eds.), Paper presented at The World Bank Conference on Development Economics. World Bank, Washington D. C. USA. Retrieved from http://documents.worldbank.org/curated/en/239281468741290885/The-role-of-the-statein-financial-markets

Verma, N., \& Mahajan, N. (2015). International Financial Integration and Economic Growth in India: An Empirical Investigation. Eurasian Journal of Business and Economics, 8(16), 121-137. https://doi.org/10.17015/ejbe.2015.016.07

$\mathrm{Xu}, \mathrm{Z}$. (2000). Financial development, investment, and economic growth. Economic Inquiry, 38(2), 331-344. https://doi.org/10.1111/j.1465-7295.2000.tb00021.x 